\title{
Synthesis of 2-halo-2H-azirines
}

\author{
Teresa M. V. D. Pinho e Melo, Cláudia S. J. Lopes, Ana L. Cardoso and \\ António M. d'A. Rocha Gonsalves \\ Departamento de Química, Faculdade de Ciências e Tecnologia, Universidade de Coimbra, 3004-535 Coimbra, Portugal
}

Received 13 April 2001; revised 18 May 2001; accepted 30 May 2001

\begin{abstract}
Oxophosphonium ylides react with $N$-chlorosuccinimide, $N$-bromosuccinimide and $N$-iodosuccinimide in the presence of azidotrimethylsilane giving the corresponding haloazidoalkenes which were completely converted to the 2-halo- $2 \mathrm{H}$-azirines on heating in heptane. (c) 2001 Elsevier Science Ltd. All rights reserved.
\end{abstract}

\section{Introduction}

We have previously described a non-classical Wittig reaction which offers a route to some simple tetrasubstituted alkenes of a type that was poorly represented in the literature. ${ }^{1}$ Diethyl 2-oxo-3-triphenylphosphoranylidene-butanedioate 1a reacts with chlorine and bromine in the presence of a range of nucleophiles giving 2,3-disubstituted diethyl butenedioates with elimination of triphenylphosphine oxide (Scheme 1). The reaction of $N$-bromosuccinimide and $\mathrm{N}$-chlorosuccinimide in methanol or in the presence of azidotrimethylsilane also gave 2,3-disubstituted diethylbutenedioates. Several of the reactions were highly stereoselective whereas others gave both $(E)$ and $(Z)$ isomers.

The study of the reactivity of ylides $\mathbf{1 b}-\mathbf{d}$ towards reagent systems XY (electrophile/nucleophile), where $\mathrm{X} \neq \mathrm{Y}$, clearly indicates that the electrophile binds exclusively to the carbon of the phosphoranylidene group of the starting ylide and the oxygen which is eliminated in the process is always from the keto carbonyl group. ${ }^{2}$

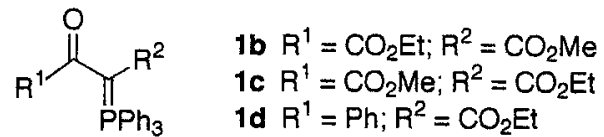

We postulated that isomeric halonium ions were intermediates in the formation of the observed products. These halonium ions could interconvert by way of an acyclic cation. The opening of the two halonium ions by a nucleophile would lead to the isomeric alkenes after the elimination of triphenylphosphine oxide (Scheme 2).

Keywords: 2-halo-2H-azirines; haloazidoalkenes; phosphorus ylides; pyrazine-2,3,5,6-tetracarboxylate.

* Corresponding author. Tel: +351-239-852-080; fax: +351-239-826-068;

e-mail: tmelo@lyra.ci.uc.pt

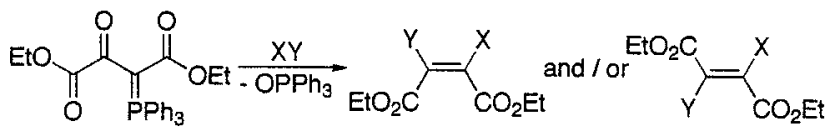

1a

Scheme 1.

The formation of an halophosphonium salt as an intermediate is in agreement with the known halogenation of $\alpha$ oxophosphonium ylides which gives the corresponding halophosphonium salt $2^{3}$ (Scheme 3 ).

On the other hand, one example is known of an intramolecular non-classical Wittig reaction of the type described above. In fact the reaction of $\alpha$-oxophosphonium ylides, bearing a terminal carboxylic acid group acting as the nucleophile, with halogenating agents leads to the formation of $E$ - and Z-halo enol lactones. ${ }^{4,5}$ The cyclization is also thought to proceeds via a halophosphonium salt followed

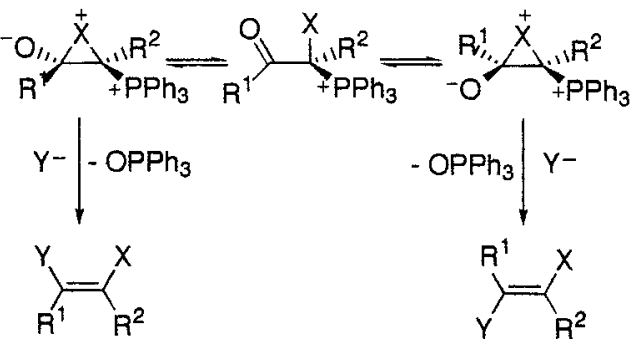

Scheme 2.

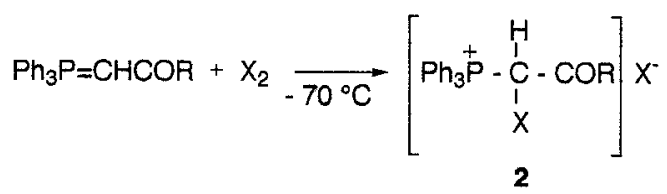

Scheme 3. 


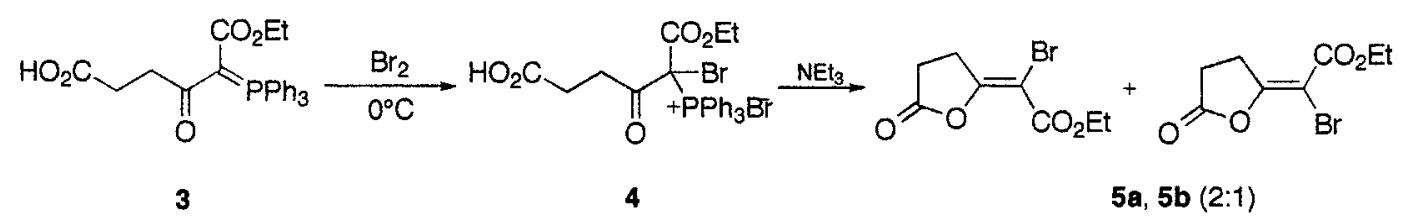

Scheme 4.

by loss of triphenylphosphine oxide. Scheme 4 illustrates one case where it is possible to isolate the bromophosphonium salt $\mathbf{4}$ if the reaction of ylide $\mathbf{3}$ with bromine is promoted at $0^{\circ} \mathrm{C}$. Treatment of $\mathbf{4}$ with triethylamine gives the corresponding bromo enol lactones. ${ }^{5}$

One aspect of particular interest in this methodology for the synthesis of tetrasubstituted alkenes is the possibility of preparing haloazidoalkenes from the reaction of phosphorus ylides with $N$-halosuccinimide in the presence of azidotrimethylsilane since these compounds were potential precursors of 2-halo- $2 \mathrm{H}$-azirines.

$2 \mathrm{H}$-Azirines are unsaturated three-membered heterocycles which are used for various synthetic purposes due to their high reactivity. ${ }^{6}$ The most general method of synthesis of $2 \mathrm{H}$-azirines is the thermal or photochemical decomposition of vinyl azides involving vinyl nitrenes as intermediates. ${ }^{6-9}$ There are very few literature reports of halo substituted azirines. $^{8,9}$ The reaction of iodine azide ${ }^{8 \mathrm{a}, \mathrm{b}}$ or chlorine azide $^{8 \mathrm{c}}$ with chloroalkenes followed by elimination of hydrogen iodide or hydrogen chloride gives the corresponding chlorovinyl azides which can be converted into chloroazirines $(\mathbf{6 a}-\mathbf{c})$. There are also a few examples of fluorinated $2 H$-azirines, such as $7 \mathbf{a}$ and $\mathbf{7 b}$, prepared from fluorovinyl azides. ${ }^{9 \mathrm{a}, \mathrm{b}}$

$$
\begin{array}{ll}
6 a R^{1}=R^{2}=M e & 7 a R^{1}=F_{i} R^{2}=C F_{3} \\
6 b R^{1}=P h ; R^{2}=M e & 7 b R^{1}=C_{3} ; R^{2}=F \\
6 c R^{1}=R^{2}=P h &
\end{array}
$$

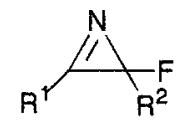

In the course of our work we have found that haloazidoalkenes prepared from phosphorus ylides can be easily converted into the corresponding 2-halo- $2 \mathrm{H}$-azirines. ${ }^{10,11}$ In this paper, we describe this general route to 2 -halo- $2 \mathrm{H}$ azirines starting from phosphorus ylides which allowed the synthesis of the first examples of 2-bromo- and 2-iodo- $2 \mathrm{H}$ azirine derivatives.

\section{Results and discussion}

Aiming the synthesis of a variety of 2 -halo- $2 \mathrm{H}$-azirines in order to evaluate the scope of the synthetic methodology, a variety of stabilised ylides were selected. $\alpha$-Oxoalkylidenetri-phenylphosphoranes bearing two carboxylate substituents (1a and 1f), derivatives with a phenyl and a carboxylate group (1d and 1e), ylide $\mathbf{1 g}$ with a carboxylate group and a benzoyl group and ylide $\mathbf{1 h}$ with a methyl and a carboxylate group as substituents were prepared using synthetic procedures described in the literature. ${ }^{12-14}$

These ylides reacted with $N$-halosuccinimide in the presence of azidotrimethylsilane giving the corresponding haloazidoalkenes 8a-f and $8 \mathrm{~h}-\mathbf{n}$ (Scheme 5). The alkene 8g could not be isolated since the reaction of ylide 1e with $\mathrm{N}$-bromosuccinimide and azidotrimethylsilane led directly to the synthesis of 2-bromo- $2 \mathrm{H}$-azirine $9 \mathrm{~g}$ in $89 \%$ yield. Alkenes 8d-f could be characterised by IR spectroscopy but attempts to purify these alkenes in order to get the complete characterisation data led to the isolation of the corresponding $2 \mathrm{H}$-azirines. These results indicate that the conversion of 3-azido-2-halo-3-phenylpropenoates to

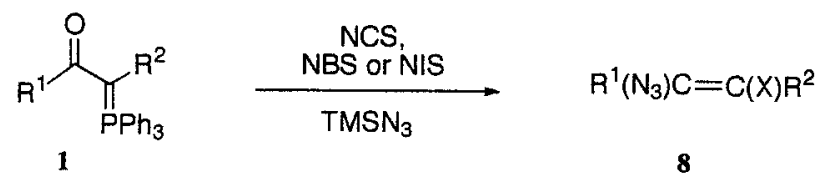

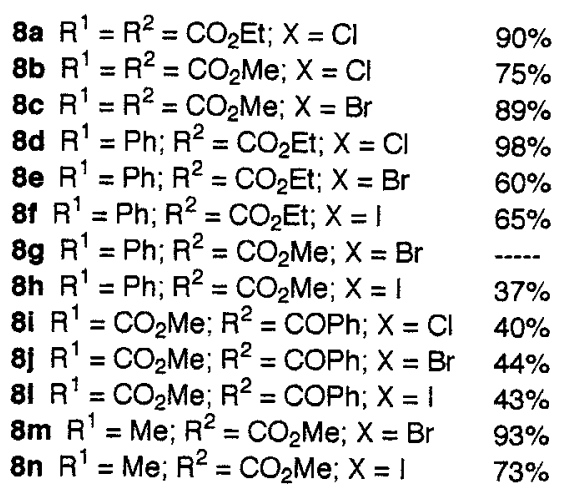


Table 1. ${ }^{13} \mathrm{C}$ NMR in $\mathrm{CDCl}_{3}$ of the haloazidoalkenes ( $\delta$ in ppm)

\begin{tabular}{lrl}
\hline Alkene & $\mathrm{C}-\mathrm{X}$ & $\mathrm{C}-\mathrm{N}_{3}$ \\
\hline $\mathbf{8 a}$ & 114.8 & 136.8 \\
$\mathbf{8 b}$ & 114.3 & 137.6 \\
$\mathbf{8 c}$ & 105.4 & 138.9 \\
$\mathbf{8 h}$ & 73.5 & 153.9 \\
$\mathbf{8 i}$ & 129.6 & 134.3 \\
$\mathbf{8 j}$ & 117.6 & 133.9 \\
$\mathbf{8 m}$ & 99.9 & 143.9 \\
$\mathbf{8 n}$ & 72.9 & 146.1 \\
\hline
\end{tabular}

${ }^{\text {a }}$ Major component

2-halo-3-phenyl- $2 \mathrm{H}$-azirine-2-carboxylate is extremely favourable.

The reactions with $\mathrm{N}$-chlorosuccinimide and $\mathrm{N}$-bromosuccinimide were completed after $5 \mathrm{~min}$. However, the reaction with $\mathrm{N}$-iodosuccinimide required the use of excess of this halogenating agent and was only completed after $4.5 \mathrm{~h}$.

The majority of these reactions showed high stereoselectivity leading to the synthesis of the alkenes as single isomers $(\mathbf{8 d}-\mathbf{n})$. However, the 2-azido-3-halobut-2-enedioates $(\mathbf{8 a}-$ c) were obtained as mixtures of $E / Z$ isomers.

The ${ }^{13} \mathrm{C}$ NMR spectra of the haloazidoalkenes show the $\mathrm{C}-\mathrm{X}$ carbon between 72.9 and 129.6 and the $\mathrm{C}-\mathrm{N}_{3}$ between 133.9 and $146.1 \mathrm{ppm}$ (Table 1). In the case of the 2-azido-3chlorobut-2-enedioates $(\mathbf{8 a}-\mathbf{c})$ the assignment was made on the basis of a comparison of its ${ }^{13} \mathrm{C}$ NMR spectra with those of dimethyl azidofumarate and dimethyl azidomaleate. ${ }^{7}$ The completed assignment of the ${ }^{13} \mathrm{C}$ NMR spectrum of methyl 2-azido-3-bromo-3-benzoylprop-2-enoate 8j was supported by ${ }^{1} \mathrm{H}-{ }^{1} \mathrm{H}$ COSY and ${ }^{1} \mathrm{H}-{ }^{13} \mathrm{C}$ COSY spectra.

Alkenes $8 \mathbf{a}-\mathbf{f}$ and $\mathbf{8 h}-\mathbf{n}$ are easily converted into the corresponding 2-halo-2H-azirines $(\mathbf{9 a}-\mathbf{f}, \mathbf{9 h}-\mathbf{n})$ on heating in heptane for $2-3 \mathrm{~h}$ (Scheme 6). The reaction can be followed by TLC and by IR by monitoring the disappearance of the band corresponding to the azido group of the starting azidoalkenes $\left(\nu \sim 2110-2120 \mathrm{~cm}^{-1}\right)$. 2-Chloro- $2 H$-azirines
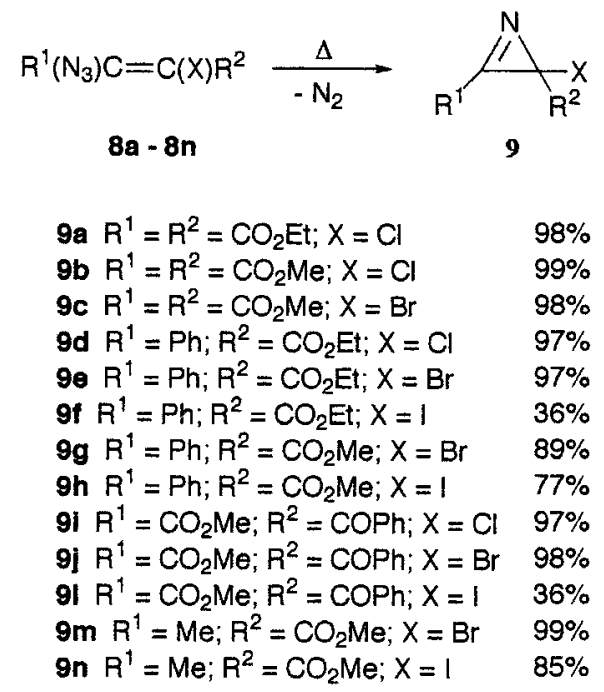

Scheme 6.
Table 2. ${ }^{13} \mathrm{C}$ NMR in $\mathrm{CDCl}_{3}$ of the $2 H$-azirines $9 \mathbf{a}-\mathbf{e}, \mathbf{9 g}-\mathbf{j}, \mathbf{9 m}$ and $\mathbf{9 n}(\delta$ in $\mathrm{ppm}$ )

\begin{tabular}{lll}
\hline $2 H$-Azirine & $\mathrm{C}-2$ & $\mathrm{C}-3$ \\
\hline $\mathbf{9 a}$ & 63.3 & 154.7 \\
$\mathbf{9 b}$ & 54.6 & 155.0 \\
$\mathbf{9 c}$ & 42.9 & 155.0 \\
$\mathbf{9 d}$ & 54.0 & 163.5 \\
$\mathbf{9 e}$ & 44.2 & 164.5 \\
$\mathbf{9 g}$ & 43.7 & 164.4 \\
$\mathbf{9 i}$ & 54.4 & 166.4 \\
$\mathbf{9 j}$ & 42.8 & 165.9 \\
$\mathbf{9 m}$ & 43.4 & 166.9 \\
$\mathbf{9 n}$ & 13.7 & 166.6 \\
\hline
\end{tabular}

and 2-bromo- $2 \mathrm{H}$-azirines were obtained in high yield (8999\%) whereas the yields obtained in the synthesis of the 2-iodo- $2 \mathrm{H}$-azirine derivatives ranged from 36 to $85 \%$.

The ${ }^{13} \mathrm{C}$ NMR spectra of the 2-chloro- and 2-bromo- $2 \mathrm{H}$ azirines show the $\mathrm{sp}^{2}$ carbon between 155.0 and $166.9 \mathrm{ppm}$ and the $\mathrm{sp}^{3}$ carbon between 43 and $63 \mathrm{ppm}$ depending on the substitution pattern. Compounds $\mathbf{9 b}$ and 9i show the signal for the $\mathrm{sp}^{3}$ carbon coincident with the signal for the methyl group. Methyl 2-iodo-3-methyl-2Hazirine-3-carboxylate 9n shows the $\mathrm{sp}^{2}$ carbon at $166.6 \mathrm{ppm}$ and the $\mathrm{sp}^{3}$ carbon at $13.7 \mathrm{ppm}$ (Table 2).

On attempting to obtain mass spectra of 2-halo- $2 \mathrm{H}$-azirines 9a-c, using chemical ionisation with ammonia, we could only observe the spectra of the corresponding pyrazine2,3,5,6-tetracarboxylate (10a and 10b).

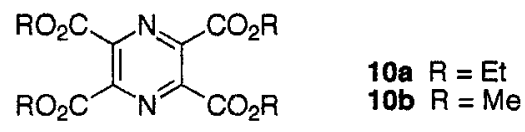

To confirm this observation tetramethyl pyrazine-2,3,5,6tetracarboxylate 10b was prepared by heating a solution of dimethyl 2-bromo-2H-azirine-2,3-dicarboxylate 9c in heptane for $17 \mathrm{~h}$ (Scheme 7). Using this procedure pyrazine 10b was obtained in low yield (2\%).

The comparison of the mass spectrum of pyrazine $\mathbf{1 0 b}$ with the mass spectra obtained from azirines $\mathbf{9 b}$ and $\mathbf{9 c}$ confirmed that they were identical. This result allowed us to conclude that 2-halo- $2 \mathrm{H}$-azirines $\mathbf{9 a}-\mathbf{c}$ undergo auto-condensation to give pyrazine-2,3,5,6-tetracarboxylates when subjected to the conditions required to obtain the mass spectra.

Chloro- and bromo- $2 \mathrm{H}$-azirines with electron withdrawing groups at C-3 decomposed in the condensed phase within 2-3 days at room temperature whereas azirines with a phenyl or methyl group at C-3 showed more stability.

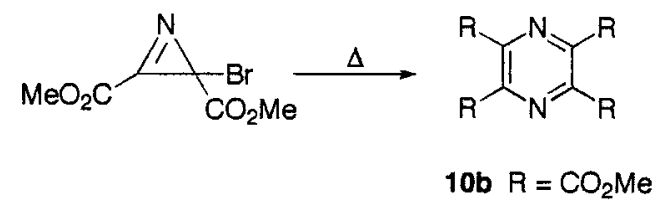

Scheme 7. 
The iodo- $2 H$-azirines showed lower stability than the corresponding chloro and bromo derivatives.

\section{Conclusion}

This work has provided a very general and efficient route to 2-halo- $2 \mathrm{H}$-azirines starting from phosphorus ylides. A range of 2-chloro-, 2-bromo- and 2-iodo- $\mathrm{H}$-azirines bearing a variety of substituents were obtained including derivatives having electron withdrawing groups at $\mathrm{C}-2$ and $\mathrm{C}-3$ $(9 \mathbf{a}-\mathbf{c}, 9 \mathbf{i}, 9 \mathbf{j}$ and 9l), 2-halo- $2 \mathrm{H}$-azirines bearing electron withdrawing groups at $\mathrm{C}-2$ and a phenyl at C-3 (9d-h) and 2-halo-2H-azirine derivatives having an electron withdrawing group at C-2 and a methyl group at C-3 (9m and 9n).

\section{Experimental}

${ }^{1} \mathrm{H}$ NMR spectra were recorded on a Bruker AMX300 instrument operating at $300 \mathrm{MHz} .{ }^{13} \mathrm{C}$ spectrum were recorded on a Brucker AMX300 instrument operating at $75.5 \mathrm{MHz}$. The solvent is deuteriochloroform except where indicated otherwise. IR spectra were recorded on a Perkin-Elmer 1720X FTIR spectrometer. Mass spectra were recorded under electron impact at $70 \mathrm{eV}$ on a VG Micromass $7070 \mathrm{E}$ instrument or where indicated, by chemical ionisation with ammonia (CI). Mp's were recorded on a Reichert hot stage and are uncorrected. Flash column chromatography was performed with Merck 9385 silica as the stationary phase. Phosphorus ylides were prepared using general procedures described in the literature $\left(\mathbf{1 a},{ }^{12} \mathbf{1 f},{ }^{12} \mathbf{1 d},{ }^{13} \mathbf{1 e},{ }^{13} \mathbf{1}{ }^{13}\right.$ and $\left.\mathbf{1 h}{ }^{14}\right)$.

\subsection{General procedure for the synthesis of chloro- and bromoazidoalkenes}

The ylide $(4.5 \mathrm{mmol})$ was dissolved in dichloromethane $(50 \mathrm{~mL})$ and a solution of azidotrimethyilsilane $(0.71 \mathrm{~g}, 6.5 \mathrm{mmol})$ and $N$-chloro- or $N$-bromosuccinimide $(6.5 \mathrm{mmol})$ in dichloromethane $(100 \mathrm{~mL})$ was added. The reaction was complete after $5 \mathrm{~min}$. The residue obtained upon removal of the solvent was purified by column chromatography and gave the vinyl azide.

4.1.1. Diethyl 2-azido-3-chlorobut-2-enedioate 8a. The title compound was purified by column chromatography [ethyl acetate/hexane (3:1)] and isolated directly as an oil as a mixture of isomers (90\%). $\nu_{\max }$ (film) 1601,1734 and $2125 \mathrm{~cm}^{-1} ; \delta_{\mathrm{H}} 1.25-1.39(\mathrm{~m}, 6 \mathrm{H}), 4.28$ and $4.38(\mathrm{q}$, together $4 \mathrm{H}) ; \delta_{\mathrm{C}} 13.8,13.9,62.7,63.2,114.8(\mathrm{C}-\mathrm{Cl})$, $136.8\left(\mathrm{C}-\mathrm{N}_{3}\right), 160.6$ and 161.8. Accurate mass $(\mathrm{CI})$ : 247.036. $\mathrm{C}_{8} \mathrm{H}_{10} \mathrm{ClN}_{3} \mathrm{O}_{4}$ requires 247.036.

4.1.2. Dimethyl 2-azido-3-chlorobut-2-enedioate 8b. The title compound was purified by column chromatography [dichloromethane] $(75 \%) . \delta_{\mathrm{H}}$ [both isomers (32:68)] 3.83 and 3.86 (s, together $3 \mathrm{H}), 3.91$ and 3.95 (s, together $3 \mathrm{H})$. Major isomer (isolated from the mixture by crystallization): $\mathrm{mp} 48-50^{\circ} \mathrm{C}$ (from pentane) (Found: $\mathrm{C}, 33.07 ; \mathrm{H}, 2.79 ; \mathrm{N}$, 18.60. $\mathrm{C}_{6} \mathrm{H}_{6} \mathrm{ClN}_{3} \mathrm{O}_{4}$ requires $\mathrm{C}, 32.88 ; \mathrm{H}, 2.74 ; \mathrm{N}, 19.18 \%$ ); $\nu_{\max }(\mathrm{KBr}) 1678,1709,1721$ and $2137 \mathrm{~cm}^{-1} ; \delta_{\mathrm{H}} 3.83(3 \mathrm{H}$, s) and $3.91(3 \mathrm{H}, \mathrm{s}) ; \delta_{\mathrm{C}} 63.5,63.7,114.3(\mathrm{C}-\mathrm{Cl}), 137.6$ $\left(\mathrm{C}-\mathrm{N}_{3}\right), 161.2$ and 162.3. Accurate mass (CI): 220.012 $[\mathrm{MH}]^{+} . \mathrm{C}_{6} \mathrm{H}_{7} \mathrm{ClN}_{3} \mathrm{O}_{4}$ requires 220.012 .

4.1.3. Dimethyl 2-azido-3-bromobut-2-enedioate 8c. The title compound was purified by column chromatography [dichloromethane] and was isolated directly as an oil (89\%). ${ }^{1} \mathrm{H}$ NMR [both isomers (24:76)] 3.83 and 3.84 (s, together $3 \mathrm{H}), 3.92$ and 3.93 (s, together $3 \mathrm{H})$. Major isomer (isolated from the mixture by crystallization): $\mathrm{mp} 49-50^{\circ} \mathrm{C}$ (from ethyl ether/pentane); $\nu_{\max }(\mathrm{KBr}) 1599,1737$ and $2120 \mathrm{~cm}^{-1} ; \delta_{\mathrm{H}} 3.83(3 \mathrm{H}, \mathrm{s})$ and $3.92(3 \mathrm{H}, \mathrm{s}) ; \delta_{\mathrm{C}} 53.9$, 54.0, $105.4(\mathrm{C}-\mathrm{Br}), 138.9\left(\mathrm{C}-\mathrm{N}_{3}\right), 161.4$ and 163.4. Accurate mass $(\mathrm{CI}): 263.961[\mathrm{MH}]^{+} . \mathrm{C}_{6} \mathrm{H}_{7} \mathrm{BrN}_{3} \mathrm{O}_{4}$ requires 263.961 .

4.1.4. Ethyl 3-azido-2-chloro-3-phenylpropenoate 8d. The title compound was purified by column chromatography [ethyl acetate/hexane (3:1)] and was isolated directly as an oil (98\%). It can be characterized by IR spectroscopy [ $\nu_{\max }$ (film) 1697, 1734, 2120 and $2986 \mathrm{~cm}^{-1}$ ] and ${ }^{1} \mathrm{H}$ NMR $\left[\delta_{\mathrm{H}} 1.26(3 \mathrm{H}, \mathrm{t})\right.$ and $\left.4.12(2 \mathrm{H}, \mathrm{q})\right]$. Attempts to purify this alkene in order to get more characterization data led to the isolation of the corresponding $2 \mathrm{H}$-azirine.

4.1.5. Ethyl 3-azido-2-bromo-3-phenylpropenoate 8e. The title compound was purified by column chromatography [ethyl acetate/hexane (3:1)] and was isolated directly as an oil $(60 \%)$. It can be characterized by IR spectroscopy $\left[\nu_{\max }\right.$ (film) 1695 and $2135 \mathrm{~cm}^{-1}$ ]. Attempts to purify this alkene in order to get more characterization data led to the isolation of the corresponding $2 \mathrm{H}$-azirine.

4.1.6. Methyl 2-azido-3-chloro-3-benzoylpropenoate 8i. The title compound was purified by column chromatography [ethyl acetate/hexane (6:1)] and was isolated directly as a solid (40\%). Mp 62-64 ${ }^{\circ} \mathrm{C}$. (Found: C, 49.0; H, 2.7; N, 15.8. $\mathrm{C}_{11} \mathrm{H}_{8} \mathrm{ClN}_{3} \mathrm{O}_{3}$ requires $\left.\mathrm{C}, 49.7 ; \mathrm{H}, 3.0 ; \mathrm{N}, 15.8 \%\right), \nu_{\max }$ $(\mathrm{KBr}) 1674,1732$ and $2137 \mathrm{~cm}^{-1} ; \delta_{\mathrm{H}} 3.58(3 \mathrm{H}, \mathrm{s}), 7.48$ $(2 \mathrm{H}, \mathrm{t}, J=16 \mathrm{~Hz}, \mathrm{Ar}-\mathrm{H}), 7.60-7.64(1 \mathrm{H}, \mathrm{m}, \mathrm{Ar}-\mathrm{H})$ and 7.87-7.89 (2H, m, Ar-H); $\delta_{\mathrm{C}} 53.1,129.0,129.4,129.6$ $(\mathrm{C}-\mathrm{Cl}), 134.1,134.3\left(\mathrm{C}-\mathrm{N}_{3}\right), 160.4$ and 187.5. Accurate mass (CI): $283.059\left[\mathrm{M}+\mathrm{NH}_{4}\right]^{+} \cdot \mathrm{C}_{11} \mathrm{H}_{12} \mathrm{ClN}_{4} \mathrm{O}_{3}$ requires 283.059 .

4.1.7. Methyl 2-azido-3-bromo-3-benzoylpropenoate 8j. The title compound was purified by column chromatography [ethyl acetate/hexane (6:1)] and was isolated directly as a solid (44\%). Mp $73-74^{\circ} \mathrm{C}$. (Found: C, 42.6; H, 2.6; N, 13.4. $\mathrm{C}_{11} \mathrm{H}_{8} \mathrm{BrN}_{3} \mathrm{O}_{3}$ requires $\left.\mathrm{C}, 42.6 ; \mathrm{H}, 2.6 ; \mathrm{N}, 13.6 \%\right)$. $\nu_{\max }$, (film) $1601,1663,1732$ and $2124 \mathrm{~cm}^{-1} ; \delta_{\mathrm{H}} 3.57(3 \mathrm{H}, \mathrm{s})$, 7.48-7.53 (2H, m, Ar-H, H-C-m), 7.60-7.63 (1H, m, Ar$\mathrm{H}, \mathrm{H}-\mathrm{C}-p)$ and 7.87-7.91 (2H, m, Ar-H, H-C-o); $\delta_{\mathrm{C}} 53.2$ $\left(\mathrm{CH}_{3}\right), 117.6(\mathrm{C}-\mathrm{Br}), 128.8(\mathrm{Ar}, \mathrm{C}-m), 129.4$ (Ar, C-o), 131.2 (Ar, C-ipso), $133.9\left(\mathrm{C}-\mathrm{N}_{3}\right), 134.1$ (Ar, C-p), 159.9 $\left(\mathrm{CO}_{2} \mathrm{CH}_{3}\right)$ and 188.1 (COPh). Accurate mass (CI): 327.009 $\left[\mathrm{M}+\mathrm{NH}_{4}\right]^{+} . \mathrm{C}_{11} \mathrm{H}_{12} \mathrm{BrN}_{4} \mathrm{O}_{3}$ requires 327.009.

4.1.8. Methyl 3-azido-2-bromobut-2-enoate 8m. The title compound was purified by column chromatography [dichloromethane] and was isolated directly as an oil (93\%). $\nu_{\max }$ (film) 1673, 1745 and $2131 \mathrm{~cm}^{-1} ; \delta_{\mathrm{H}} 2.30$ $(3 \mathrm{H}, \mathrm{s}), 3.74(3 \mathrm{H}, \mathrm{s}) ; \delta_{\mathrm{C}} 20.1,52.8,99.9(\mathrm{C}-\mathrm{Br}), 143.9$ 
$\left(\mathrm{C}-\mathrm{N}_{3}\right)$ and 162.6. Accurate mass $(\mathrm{CI}): 219.972[\mathrm{MH}]^{+}$. $\mathrm{C}_{5} \mathrm{H}_{7} \mathrm{BrN}_{3} \mathrm{O}_{2}$ requires 219.972 .

\subsection{General procedure for the synthesis of the iodoazidoalkenes}

The ylide $(4.5 \mathrm{mmol})$ was dissolved in dichloromethane $(50 \mathrm{~mL})$ and a solution of azidotrimethyilsilane $(0.71 \mathrm{~g}$, $6.5 \mathrm{mmol})$ and $N$-iodosuccinimide $(13 \mathrm{mmol})$ in dichloromethane $(100 \mathrm{~mL})$ was added. The reaction was complete after $4.5 \mathrm{~h}$. The residue obtained upon removal of the solvent was purified by column chromatography [ethyl acetate/hexane (1:2)] giving the vinyl azide.

4.2.1. Ethyl 3-azido-2-iodo-3-phenylpropenoate 8f. $65 \%$. $\nu_{\max }\left(\right.$ film) 1691,2114 and $2983 \mathrm{~cm}^{-1} ; \delta_{\mathrm{H}} 0.92(3 \mathrm{H}, \mathrm{t}), 3.95$ $(2 \mathrm{H}, \mathrm{q}), 7.27-7.31(2 \mathrm{H}, \mathrm{m}, \mathrm{Ar}-\mathrm{H}), 7.46-7.51$ (1H, m, Ar$\mathrm{H})$ and 7.61-7.69 (2H, m, Ar-H).

4.2.2. Methyl 3-azido-2-iodo-3-phenylpropenoate $8 \mathbf{h}$. $37 \%$. $\nu_{\max }$ (film) 1693, 1716, 2135 and $2999 \mathrm{~cm}^{-1} ; \delta_{\mathrm{H}}$ $3.51(3 \mathrm{H}, \mathrm{s}), 7.26-7.29(2 \mathrm{H}, \mathrm{m}, \mathrm{Ar}-\mathrm{H}), 7.43-7.49(1 \mathrm{H}$, $\mathrm{m}, \mathrm{Ar}-\mathrm{H})$ and 7.59-7.65 $(2 \mathrm{H}, \mathrm{m}, \mathrm{Ar}-\mathrm{H}) ; \delta_{\mathrm{C}} 52.9,73.5$ $(\mathrm{C}-\mathrm{I}), 153.9\left(\mathrm{C}-\mathrm{N}_{3}\right)$ and 172.5 .

4.2.3. Methyl 2-azido-3-iodo-3-benzoylpropenoate 81. $43 \%$. $\nu_{\max }$ (film) 1660,1724 and $2125 \mathrm{~cm}^{-1} ; \delta_{\mathrm{H}} 3.57(3 \mathrm{H}$, s) and 7.47-7.90 (5H, m, Ar-H).

4.2.4. Methyl 3-azido-2-iodo-but-2-enoate 8n. The titled compound was isolated directly as an oil $(73 \%) . \nu_{\max }$ (film) 1709 and $2110 \mathrm{~cm}^{-1} ; \delta_{\mathrm{H}} 2.43(3 \mathrm{H}, \mathrm{s})$ and $3.81(3 \mathrm{H}, \mathrm{s}) ; \delta_{\mathrm{C}}$ 23.7, 63.1, $72.9(\mathrm{C}-\mathrm{I}), 146.1\left(\mathrm{C}-\mathrm{N}_{3}\right)$ and 164.6.

\subsection{General procedure for the synthesis of $\mathbf{2 H}$-azirines}

A solution of the vinyl azide $(2.0 \mathrm{mmol})$ in heptane $(10 \mathrm{~mL})$ was heated under reflux for $2-3 \mathrm{~h}$ (the reaction was monitored by TLC). The reaction mixture was cooled and the solvent evaporated giving the azirine.

4.3.1. Diethyl 2-chloro-2H-azirine-2,3-dicarboxylate 9a. The title compound was isolated directly as an oil (98\%). $\nu_{\max }\left(\right.$ film) 1628 and $1733 \mathrm{~cm}^{-1} . \delta_{\mathrm{H}} 1.29(3 \mathrm{H}, \mathrm{t}), 1.43(3 \mathrm{H}$, t), $4.26(2 \mathrm{H}, \mathrm{q})$ and $4.50(2 \mathrm{H}, \mathrm{q}) ; \delta_{\mathrm{C}} 13.9,14.0,63.3(\mathrm{C}-2)$, 63.9, 64.6, 154.67 (C-3), 162.7 and 165.4; $\mathrm{m} / \mathrm{z}$ (CI) [Tetraethyl pyrazine-2,3,5,6-tetracarboxylate] 386 $\left[\mathrm{M}+\mathrm{NH}_{4}\right]^{+}(12 \%), 369[\mathrm{MH}]^{+}(5), 302(10), 285$ (100) and 203 (16).

4.3.2. Dimethyl 2-chloro-2H-azirine-2,3-dicarboxylate 9b. The title compound was isolated directly as an oil (99\%). $\nu_{\max }$ (film) 1652 and $1755 \mathrm{~cm}^{-1} . \delta_{\mathrm{H}} 3.85(3 \mathrm{H}, \mathrm{s})$ and $3.90(3 \mathrm{H}, \mathrm{s}) ; \delta_{\mathrm{C}} 54.39,54.57\left(\mathrm{C}-2\right.$ and $\left.\mathrm{CH}_{3}\right), 155.0$ (C-3), 162.6 and $165.7 ; \mathrm{m} / \mathrm{z}$ (CI) [Tetramethyl pyrazine2,3,5,6-tetracarboxylate $] \quad 330 \quad\left[\mathrm{M}+\mathrm{NH}_{4}\right]^{+}(16 \%), \quad 313$ $[\mathrm{MH}]^{+}(6), 194(62), 175(52)$ and 160 (100).

4.3.3. Dimethyl 2-bromo-2H-azirine-2,3-dicarboxylate 9c. The title compound was isolated directly as an oil $(98 \%) . \nu_{\max }\left(\right.$ film) 1653 and $1749 \mathrm{~cm}^{-1} \cdot \delta_{\mathrm{H}} 3.85(3 \mathrm{H}, \mathrm{s})$ and $4.09(3 \mathrm{H}, \mathrm{s}) ; \delta_{\mathrm{C}} 42.9(\mathrm{C}-2), 54.5,155.0(\mathrm{C}-3), 163.1$ and $165.3 ; \mathrm{m} / \mathrm{z}(\mathrm{CI})$ [Tetramethyl pyrazine-2,3,5,6-tetra- carboxylate $330\left[\mathrm{M}+\mathrm{NH}_{4}\right]^{+}(100 \%), 313[\mathrm{MH}]^{+}$(28), 194 (27), 175 (35) and 160 (26).

4.3.4. Ethyl 2-chloro-3-phenyl-2H-azirine-2-carboxylate 9d. The title compound was isolated directly as an oil (97\%). $\nu_{\max }$ (film) 1745 and $2984 \mathrm{~cm}^{-1} ; \delta_{\mathrm{H}} 1.27(3 \mathrm{H}, \mathrm{t})$, $4.27(2 \mathrm{H}, \mathrm{q}), 7.60-7.66(2 \mathrm{H}, \mathrm{m}, \mathrm{Ar}-\mathrm{H}), 7.70-7.76(1 \mathrm{H}, \mathrm{m}$, $\mathrm{Ar}-\mathrm{H})$ and $7.93-7.97(2 \mathrm{H}, \mathrm{m}, \mathrm{Ar}-\mathrm{H}) ; \delta_{\mathrm{C}} 13.9,54.0(\mathrm{C}-2)$, 63.2, 119.6, 129.6, 130.7, 134.9, 163.5 (C-3) and 167.3. Accurate mass (CI): $241.074\left[\mathrm{M}+\mathrm{NH}_{4}\right]^{+} . \mathrm{C}_{11} \mathrm{H}_{14} \mathrm{ClN}_{2} \mathrm{O}_{2}$ requires 241.074 .

4.3.5. Ethyl 2-bromo-3-phenyl-2H-azirine-2-carboxylate 9e. The title compound was isolated directly as an oil (97\%). (Found: C, 49.24; H, 5.76; N, 5.22. $\mathrm{C}_{11} \mathrm{H}_{10} \mathrm{BrNO}_{2}$ requires $\mathrm{C}, 49.24 ; \mathrm{H}, 5.75 ; \mathrm{N}, 5.67 \%$ ). $\nu_{\max }$ (film) 1742 and $2984 \mathrm{~cm}^{-1} ; \delta_{\mathrm{H}} 1.28(3 \mathrm{H}, \mathrm{t}), 4.27(2 \mathrm{H}, \mathrm{q}), 7.61-7.66$ $(2 \mathrm{H}, \mathrm{m}, \mathrm{Ar}-\mathrm{H}), 7.71-7.77(1 \mathrm{H}, \mathrm{m}, \mathrm{Ar}-\mathrm{H})$ and 7.95$7.99(2 \mathrm{H}, \mathrm{m}, \mathrm{Ar}-\mathrm{H}) ; \delta_{\mathrm{C}} 14.1,44.2$ (C-2), 63.6, 119.8, $129.7,130.9,135.1,164.5(\mathrm{C}-3)$ and $166.7 ; \mathrm{m} / \mathrm{z}(\mathrm{EI}) \mathrm{M}^{+}$ 268 (35\%), 241 (20), 222 (10), 196 (18), 188 (86) and 89 (100).

4.3.6. Ethyl 2-iodo-3-phenyl-2H-azirine-2-carboxylate 9f. The title compound was isolated directly as an oil $(36 \%) . \delta_{\mathrm{H}} 1.28(3 \mathrm{H}, \mathrm{t}), 4.22(2 \mathrm{H}, \mathrm{q}), 7.60-7.65(2 \mathrm{H}, \mathrm{m}$, $\mathrm{Ar}-\mathrm{H}), 7.71-7.74(1 \mathrm{H}, \mathrm{m}, \mathrm{Ar}-\mathrm{H})$ and 7.91-7.94 $(2 \mathrm{H}, \mathrm{m}$,

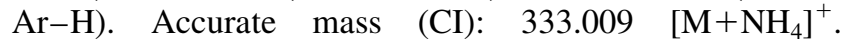
$\mathrm{C}_{11} \mathrm{H}_{14} \mathrm{IN}_{2} \mathrm{O}_{2}$ requires 333.010.

4.3.7. Methyl 2-bromo-3-phenyl-2H-azirine-2-carboxylate 9g. $89 \%$, directly from ylide 1 c and after purification by column chromatography with ethyl acetate/hexane (1:2). (Found: $\mathrm{C}, 47.46 ; \mathrm{H}, 3.11 ; \mathrm{N}, 5.48 . \mathrm{C}_{10} \mathrm{H}_{8} \mathrm{BrNO}_{2}$ requires $\mathrm{C}$, 47.27; H, 3.17; N, 5.51\%). $\nu_{\max }$ (film) 1670, 1759 and $2954 \mathrm{~cm}^{-1} ; \delta_{\mathrm{H}} 3.82(3 \mathrm{H}, \mathrm{s}), 7.62-7.67(2 \mathrm{H}, \mathrm{m}, \mathrm{Ar}-$ $\mathrm{H}), 7.72-7.78(1 \mathrm{H}, \mathrm{m}, \mathrm{Ar}-\mathrm{H})$ and $7.95-7.99(2 \mathrm{H}, \mathrm{m}$, $\mathrm{Ar}-\mathrm{H}) ; \delta_{\mathrm{C}} 43.7(\mathrm{C}-2), 54.2,119.7,129.7,131.0,135.2$, $164.4(\mathrm{C}-3)$ and 167.2.

4.3.8. Methyl 2-iodo-3-phenyl-2H-azirine-2-carboxylate 9h. $77 \%$. $\nu_{\max }$ (film) $1756 \mathrm{~cm}^{-1} ; \delta_{\mathrm{H}} 3.82(3 \mathrm{H}, \mathrm{s}), 7.63-$ $7.68(2 \mathrm{H}, \mathrm{m}, \mathrm{Ar}-\mathrm{H}), 7.73-7.79(1 \mathrm{H}, \mathrm{m}, \mathrm{Ar}-\mathrm{H})$ and $7.94-$ $7.98(2 \mathrm{H}, \mathrm{m}, \mathrm{Ar}-\mathrm{H})$. Accurate mass (EI): 301.9666. $\mathrm{C}_{10} \mathrm{H}_{9} \mathrm{INO}_{2}$ requires 301.9678 .

4.3.9. Methyl 2-benzoyl-2-chloro- $2 H$-azirine-3-carboxylate 9i. The title compound was isolated directly as an oil (97\%). $\nu_{\max }$ (film) 1680, 1748 and $2961 \mathrm{~cm}^{-1} . \delta_{\mathrm{H}} 3.85$ $(3 \mathrm{H}, \mathrm{s}), 7.56-7.64(2 \mathrm{H}, \mathrm{m}, \mathrm{Ar}-\mathrm{H}), 7.73-7.81(1 \mathrm{H}, \mathrm{m}$, $\mathrm{Ar}-\mathrm{H})$ and 8.17-8.22 (2H, m, Ar $-\mathrm{H}) ; \delta_{\mathrm{C}} 54.4(\mathrm{C}-2$ and $\left.\mathrm{CH}_{3}\right), 129.6,129.9,133.8,136.5,164.3,166.4(\mathrm{C}-3)$ and 179.1. Accurate mass (EI): 237.019. $\mathrm{C}_{11} \mathrm{H}_{8} \mathrm{ClNO}_{3}$ requires 237.019 .

4.3.10. Methyl 2-benzoyl-2-bromo-2H-azirine-3-carboxylate 9j. The title compound was isolated directly as an oil (98\%). (Found: C, 47.29; H, 2.81; N, 4.58. $\mathrm{C}_{11} \mathrm{H}_{8} \mathrm{BrNO}_{3}$ requires $\mathrm{C}, 46.84 ; \mathrm{H}, 2.86 ; \mathrm{N}, 4.97$. $\nu_{\max }$ (film) 1674,1748 and $2834 \mathrm{~cm}^{-1} ; \delta_{\mathrm{H}} 3.87(3 \mathrm{H}, \mathrm{s}), 7.60-7.65(2 \mathrm{H}, \mathrm{m}, \mathrm{Ar}-\mathrm{H})$, 7.70-7.82 (1H, m, Ar-H) and 8.21-8.25 (2H, m, Ar$\mathrm{H}) ; \delta_{\mathrm{C}} 42.8(\mathrm{C}-2), 54.6,129.5,129.9,133.8,136.5$, 164.6, $165.9(\mathrm{C}-3)$ and $178.8 ; \mathrm{m} / \mathrm{z}(\mathrm{EI})\left[\mathrm{M}\left({ }^{81} \mathrm{Br}\right)^{+}\right]$, 
$283(36 \%),\left[\mathrm{M}\left({ }^{79} \mathrm{Br}\right)^{+}\right], 281(36 \%), 128(8), 105$ (100) and 77 (91).

4.3.11. Methyl 2-benzoyl-2-iodo-2H-azirine-3-carboxylate 91. $36 \% . \delta_{\mathrm{H}} 4.10(3 \mathrm{H}, \mathrm{s}), 7.47-7.56(3 \mathrm{H}, \mathrm{m}, \mathrm{Ar}-\mathrm{H})$ and $8.00-8.07(2 \mathrm{H}, \mathrm{m}, \mathrm{Ar}-\mathrm{H})$. Accurate mass (EI): 328.9549. $\mathrm{C}_{11} \mathrm{H}_{8} \mathrm{NO}_{3} \mathrm{I}$ requires 328.9547 .

4.3.12. Methyl 2-bromo-3-methyl-2H-azirine-2-carboxylate $9 \mathrm{~m}$. The title compound was isolated directly as an oil (99\%). $\nu_{\max }$ (film) 1693 and $1747 \mathrm{~cm}^{-1} \cdot \delta_{\mathrm{H}} 2.58(3 \mathrm{H}, \mathrm{s})$ and $3.77(3 \mathrm{H}, \mathrm{s}) ; \delta_{\mathrm{C}} 10.74,43.44(\mathrm{C}-2), 53.95,166.91(\mathrm{C}-3)$ and 167.49. Accurate mass (CI): $208.992 \quad\left[\mathrm{M}+\mathrm{NH}_{4}\right]^{+}$. $\mathrm{C}_{5} \mathrm{H}_{10} \mathrm{BrN}_{2} \mathrm{O}_{2}$ requires 208.992 .

4.3.13. Methyl 2-iodo-3-methyl-2H-azirine-3-carboxylate 9n. $85 \%, \nu_{\max }\left(\right.$ film) $1734 \mathrm{~cm}^{-1} . \delta_{\mathrm{H}} 2.56(3 \mathrm{H}, \mathrm{s})$ and $3.80(3 \mathrm{H}, \mathrm{s}) ; \delta_{\mathrm{C}} 11.4,13.7(\mathrm{C}-2), 54.3,166.6(\mathrm{C}-3)$ and 167.7; m/z (CI) $257\left[\mathrm{M}+\mathrm{NH}_{4}\right]^{+}(1 \%), 239$ (2), 224 (10), 130 (4) and 86 (26). The 2-iodo- $2 H$-azirine 9n was converted into its halide displacement product on reacting with potassium phthalimide as described previously: ${ }^{11}$ methyl 2-phthalimido-3-methyl-2H-azirine-2-carboxylate $\delta_{\mathrm{H}} 2.81(3 \mathrm{H}, \mathrm{s}), 3.77(3 \mathrm{H}, \mathrm{s}), 7.76-7.79(2 \mathrm{H}, \mathrm{m})$ and $7.87-7.90(2 \mathrm{H}, \mathrm{m}) ; \delta_{\mathrm{C}} 13.0,41.2(\mathrm{C}-2), 53.3,123.8$, $131.7,134.5,159.9(\mathrm{C}-3), 167.2$ and 168.1. Accurate mass (CI): $276.098\left[\mathrm{M}+\mathrm{NH}_{4}\right]^{+} . \mathrm{C}_{13} \mathrm{H}_{14} \mathrm{~N}_{3} \mathrm{O}^{4}$ requires 276.098.

4.3.14. Tetramethyl pyrazine-2,3,5,6-tetracarboxylate 10b. $2 \%$. A solution of the dimethyl 2-bromo- $2 \mathrm{H}$-azirine2,3-dicarboxylate 9c $(2.0 \mathrm{mmol})$ in heptane $(10 \mathrm{~mL})$ was heated under reflux for $17 \mathrm{~h}$. The residue obtained upon removal of the solvent was purified by column chromatography [ethyl acetate/hexane $(1: 1)$ ] giving the pyrazine. $\mathrm{Mp}$ $180-182^{\circ} \mathrm{C}$ (lit. ${ }^{15} \mathrm{mp} 181-182^{\circ} \mathrm{C}$ ). $\nu_{\max }$ (film) 1664 and $1745 \mathrm{~cm}^{-1} . \delta_{\mathrm{H}} 4.04(12 \mathrm{H}, \mathrm{s}) ; \delta_{\mathrm{C}} 53.8,145.1$ and 163.4 . Accurate mass (CI): $313.066\left[\mathrm{M}+\mathrm{NH}_{4}\right]^{+} . \mathrm{C}_{12} \mathrm{H}_{13} \mathrm{~N}_{2} \mathrm{O}_{8}$ requires 313.067 .

\section{Acknowledgements}

The authors wish to thank Drs T. L. Gilchrist and R. Storr (University of Liverpool) for very useful discussions concerning this project. We also thank Chymiotechnon and Fundação para a Ciência e a Tecnologia (POCTI 36137/99) for financial support.

\section{References}

1. Rocha Gonsalves, A. M. d'A; Cabral, A. M. T. D. P. V.; Pinho e Melo, T. M. V. D.; Gilchrist, T. L. Synthesis 1997, 673-676.

2. Pinho e Melo, T. M. V. D.; Rocha Gonsalves, A. M. d'A.; Carrapato, S. M. S.; Taborda, A. M. O. M. P. Molecules 1999, 4, 219-231.

3. Denney, D. B.; Ross, S. T. J. Org. Chem. 1962, 27, 998-1000.

4. Murphy, P. J.; Lee, S. E. J. Chem. Soc., Perkin Trans. 1 1999, 3049-3066.

5. Abell, A. D.; Hoult, D. A.; Morris, K. M.; Taylor, J. M.; Trent, J. O. J. Org. Chem. 1995, 58, 1531-1537.

6. (a) Backes, J. Methoden der Organischen Chemie (HoubenWeyl), Vol. E16; Georg Thieme Verlag: Stuttgart, 1992; pp 316-369. (b) Padwa, A.; Woolhouse, A. D. Comprehensive Heterocyclic Chemistry, Vol. 7; Pergamon: Oxford, 1984; pp 47-93.

7. L'abbé, G.; Dekerk, J.-P.; Van Stappen, P. Bull. Soc. Chim. Belg. 1981, 90, 1073-1074.

8. (a) Ciabattoni, J.; Cabell, Jr., M. J. Am. Chem. Soc. 1971, 93, 1482-1483. (b) Padwa, A.; Blacklock, T. J.; Carlsen, P. H. J.; Pulwer, M. J. Org. Chem. 1979, 44, 3281-3287. (c) Gallagher, T. C.; Sasse, M. J.; Storr, R. C. Chem. Commun. 1979, 419-420. (d) Gallagher, T. C.; Storr, R. C. Tetrahedron Lett. 1981, 27, 2905-2908. (e) Hamana, H.; Sugasawa, T. Chem. Lett. 1985, 571-574.

9. (a) Banks, R. E.; McGlinchey, M. J. J. Chem. Soc. (C) 1970, 2172-2175. (b) Banks, R. E.; Moore, G. J. J. Chem. Soc. (C) 1966, 2304-2307. (c) Morawietz, J.; Sander, W. J. Org. Chem. 1996, 61, 4351-4354.

10. Pinho e Melo, T. M. V. D.; Rocha Gonsalves, A. M. d'A.; Lopes, C. S. J.; Gilchrist, T. L. Tetrahedron Lett. 1999, 40, 789-792.

11. Pinho e Melo, T. M. V. D.; Lopes, C. S. J.; Rocha Gonsalves, A. M. d'A. Tetrahedron Lett. 2000, 41, 7217-7220.

12. Aitken, R. A.; Hérion, H.; Janosi, A.; Raut, S. V.; Seth, S.; Shannon, I. J.; Smith, F. C. Tetrahedron Lett. 1993, 34, 56215622.

13. Aitken, R. A.; Hérion, H.; Janosi, A.; Karodia, N.; Raut, S. V.; Seth, S.; Shannon, I. J.; Smith, F. C. J. Chem. Soc., Perkin Trans. 1 1994, 2467-2471.

14. Wasserman, H. H.; Ennis, D. S.; Blum, C. A.; Rotello, V. M. Tetrahedron Lett. 1992, 33, 6003-6006.

15. (a) Williams, J. R.; Cossey, J. J.; Adler, M. J. Org. Chem. 1972, 37, 2963-2965. (b) Mager, H. I. X.; Berends, W. Recl. Trav. Chim. Pays-Bas 1960, 79, 282-284. 